\title{
THE USE OF YOUTUBE VIDEO IN TEACHING ENGLISH FOR FOREIGN LANGUAGE AT VOCATIONAL HIGH SCHOOL
}

\author{
A.A.C. Cahyana \\ English Language Education, Post Graduate Program, Universitas Pendidikan Ganesha, Singaraja \\ e-mail: agusagungcanis@gmail.com
}

The study aimed to investigate the use of YouTube video in learning English as a foreign language in terms of the implementation, students' opinion in English skill improvement after the implementation of YouTube video, the problem faced by teachers and students, and students' perception toward the use of YouTube video in learning English. The respondents were 5 tenth grade English teachers and 35 tenth grade students. This study used embedded mixed-method as the research design. The data were gathered by distributing questionnaires, and were analyzed by using SPSS. The result of the study revealed that: a) the teachers could implement the technique since the teachers used YouTube video technique to target several skills in English. The students had positive opinion about the improvement obtained in learning English. The students also mentioned that the implementation of this technique was able to decrease the monotonous teaching and increase the motivation in learning English. However, some problems occurred while the preparation of the assessment process in implementing YouTube video technique such as the internet connection and the students' readiness. The teachers needed to develop the technique to increase the students better understanding of the topic. The result of this study was found out the implementation of YouTube videos in teaching and learning English was showed a positive impact on students' English acquisition and helpful for teachers in delivering the topic to students and the result was in line with the finding of the previous study. However, there were some additional findings in this present study such as the problem the way teachers implemented this technique, the students' opinion in English skill improvement, and the students' perception toward the implementation of the YouTube video technique.

\section{Keywords: Teaching English; Vocational High School; YouTube Video}

\section{INTRODUCTION}

In this 21 century era, information and communication technology (ICT) is significantly and highly used in many sectors of human life to make an easier way of life. Hence, the 2013 curriculum and The Framework of 21st-century learning promotes integrated learning with Information and Communication Technology (ICT) as an essential knowledge to face the digital learning era (Lestari \& Prasetyo, 2019). ICT has an important role to develop many sectors such as Economy, Industry, Politics, Culture, and Education. Ratheeswari, 2018; Wasif Nisar \& Ali, 2011; Suryani, 2010 believe that ICT is very essential in improving students' educational efficiency and increase the quality of teaching effectively. ICT helped teachers to enrich their content in teaching and gives a chance to develop it. The use of the internet has given an alternative way in education as the majority of the Indonesian population has reached 171.17 million people using the internet (Kompas.com, 2019). Moreover, the internet offered many interesting platforms such as web, Instagram, Facebook, Twitter, YouTube, etc.

In teaching English as a foreign language, it is often a challenge to apply potentially useful technology, promote the students' autonomy, and create stimulating lessons (Watkins \& Wilkins, 2011). In this kind of teaching, teacher and students must have sufficient access to the internet, computer and other technological media which people nowadays are familiar with these media as entertainment. Therefore, the use of YouTube videos as a medium of teaching was easier to understand. Hedge (2000) as cited in (Gilakjani \& Sabouri, 2016) states that modern society respects the change from printed into sound media and other media like audiovisual. 
In supporting the teaching English as a foreign language process, teacher should consider an appropriate teaching technique and media for students and motivate them. In teaching a foreign language, the use of the World Wide Web (WWW) as a resource in developing English language acquisition was an essential thing to achieve a significant result (Medoukali, 2015). Video has benefits for learners because it displays body language and contextual thing and also gives students "short attention spans" (Yasin et al., 2018). People like watching videos in their daily life as entertainment but the video could be as a media in teaching and learning English as a foreign language. When people watching videos, especially English videos, unconsciously they learn their ears to listen comprehensively and processing the language. Students who watch a video can comprehend the meaning of the conversation in the video.

The online video platform which mostly accesses is YouTube. YouTube is a part of online media which contain various kind of video made by people who become its content creator. Based on (Kabooha \& Elyas, 2015) YouTube is a multidimensional resource that contains a video in all fields of knowledge that easy access. In ESL classes, the use of YouTube allows students to access native speaker language as in a natural context (Nurkholida, 2016). It can be the best option to fulfill the need for English learners in learning English as a foreign language. Teachers can use YouTube videos as a way to observe student's listening and speaking skills since it can only be enjoyed by using sight and hear (Watkins \& Wilkins, 2011).

Styati (2016) mentions that the use of YouTube enhance students' interest to study English easier. In that research, the researcher found that YouTube was an authentic material in teaching the four skills in English mastery. YouTube is a video platform that allows its users essential freedoms in expressing and sharing information. Moreover, YouTube is a free of charge media which allows its users, including learners and teachers around the world, to watch and upload their video easily (Muhammad et al. 2014). There are many teachers and content creators regularly upload their own video creation with an education theme which beneficial for English learners all over the world. Through You Tube, students could access natural communication by native speaker language (Nurkholida, 2016). Moreover, teachers were able to make YouTube as a platform for collecting students' assignments. By using YouTube as media in uploading assignments, students can improve their creativity and critical thinking because they gained their curiosity in making a creative video by themselves. It also improved their motivation in making videos since YouTube allowed them to see how many viewers have seen their videos (Rahayu \& Putri, 2019).

Some researchers found out that the use of YouTube videos enhance students English skills improvement. According to the findings of the research from Ayu (2016), Medoukali (2015), and Watkins \& Wilkins, (2011) the use of YouTube videos improved students listening skills. This is because YouTube provides both audio and visual to the learners which allowed students to figure out the speech or words they heard while learning the subject content as well as to improve their language abilities. Furthermore, the use of YouTube videos improved students speaking skills toward Vlogging and uploading video assignments on YouTube.com, this statement supported the findings of researches from Saiful (2019) and Rahayu \& Putri (2019). Furthermore, the use of YouTube videos is effective toward the students' understanding of literature as mentioned by Abdulrahman Almurashi (2016) and K. Muhammad (2012). Besides, the researcher found out that the use of YouTube in studying English is an interesting, beneficial, and providing students with opportunity to understand the discussed novel and its events better. However, in applying this YouTube video technique teacher need to facilitate with some tools such as laptop, projector, sound system, internet connection and also a qualified computer skill. This research aims to analyze the use of YouTube videos in teaching English for Foreign Language Students.

Based on the review of previous studies, the implementation and problems of using YouTube video technique in teaching English were not much elaborated. Therefore, in this present study, the researcher highlights how teachers implemented the YouTube video technique, the students' opinion about the improvement in English after learning using YouTube video, the problems encountered by teachers and students as well as students' perception on the implementation of YouTube video technique in learning English. 


\section{RESEARCH METHOD}

This research was embedded mixed-method research. The data in this study were collected by conducting five questionnaires based on the research questions. The questionnaires consisted of open-ended and close-ended questions. Thus, those data were combined to answer the research questions. The subject of this research was the English teachers which numbered 5 teachers and 35 of tenth-grade students in SMK Werdhi Sila Kumara. The reason for choosing this school was because SMK Werdhi Sila Kumara is one of the favorites schools in Gianyar area which focuses on the tourism field. It can be assumed that the students in this school need to learn English as more as they can because they were prepared to be ready in the tourism industry which needs to work with good competency in English. Besides, the research object which observed in this research was the implementation of YouTube video as a teaching technique, students' opinion of the use of YouTube video in English, the problem faced by students and teachers, and the student's perception toward the use of YouTube as a media in learning English.

To collect the data in this research, the researcher used the researcher as the main instrument and questionnaire to collect more data. The questionnaire was given to both teachers and students to analyze the implementation of YouTube video in learning English, student's opinions of the use of YouTube video in learning English, problems faced by both teachers and students, and the students' perception toward the use of YouTube video in learning English.

In this study, the data were analyzed both quantitatively and qualitatively. The quantitative method was used to calculate the result of questionnaires while the qualitative method was used to describe the data. The process of data analysis in this research was explained in the following paragraph. There were 2 instruments in this study, there were researchers and questionnaires. There were 5 kinds of questionnaires such as teachers' implementation of YouTube videos, students' achievement, teachers' problems, students' problems, and students' perceptions.

The first step in analyzing the data was collecting the responses. The responses of the questionnaires as the data obtained from the teachers and students. After collecting the responses, the next step was computing the data into SPSS. The SPSS was used to calculate the mean score of each response in the questionnaire. The last step was to categorize the result of the data into the scale categorization. This was important to know the level of criteria of the responses.

\section{FINDINGS AND DISCUSSION}

This research conducted in order to find out the implementation of YouTube video in teaching English as a foreign language to ten grade students, the students' opinion in English skill improvement after YouTube video was used as technique of teaching, to find out the problem faced by the teachers and students while implementing YouTube video, and to find out the students' perception toward the use of YouTube as a media in learning English. The subject of the research was 5 tenth grade English teachers of SMK Werdhi Sila Kumara and 1 class consist of 35 students. Both teachers and students were given a questionnaire based on the research questions to gain the data. There were 2 instruments in this study, there were researcher and questionnaires. There were 5 kinds of questionnaires such as teachers' implementation of YouTube Video, students' opinion, teachers' problem, students' problem, and students' perception. After collecting the data from questionnaires, the data processed using SPSS to find out the mean score of each item in the questionnaires to categorize the result on a Likert scale.

The result showed that most of the respondents gave positive responses to the implementation of YouTube videos as teaching media in the class. Therefore, this positive response can be indicating that the teachers understand how to implement YouTube videos in the class as a medium of Teaching English as a Foreign Language. Based on the data of the respondents, it can be seen that the teachers were ready to implement a YouTube video in the class from preparing the lesson plan, implementing the technique in the class, and assess students. Moreover, the school was ready to support the implementation of YouTube videos in the class as a teaching medium. It can be seen from the availability of the supporting equipment needed in teaching activity in the class. 
Table 1. The Steps of Implementing YouTube Video

\begin{tabular}{|c|c|c|c|}
\hline No. & Steps & Item & Category \\
\hline \multirow[t]{6}{*}{1} & Preparation & $\begin{array}{l}\text { Preparing everything needed for learning } \\
\text { activities }\end{array}$ & Often \\
\hline & & $\begin{array}{l}\text { Wrote clearly the title and link in the } \\
\text { lesson plan that I made. }\end{array}$ & Often \\
\hline & & $\begin{array}{l}\text { Using learning media in class to } \\
\text { implement YouTube }\end{array}$ & Often \\
\hline & & $\begin{array}{l}\text { Choosing a video with a duration that } \\
\text { suits my learning }\end{array}$ & Often \\
\hline & & Looking for learning media on YouTube & Always \\
\hline & & $\begin{array}{l}\text { Using YouTube as a source of learning } \\
\text { videos. }\end{array}$ & Often \\
\hline 2 & Opening & $\begin{array}{l}\text { Giving questions related to the topic of } \\
\text { learning to students. }\end{array}$ & Always \\
\hline \multirow[t]{4}{*}{3} & Main Activity & $\begin{array}{l}\text { Students focus on learning when using } \\
\text { YouTube. }\end{array}$ & Often \\
\hline & & $\begin{array}{l}\text { Students can discuss well according to } \\
\text { the topic of learning. }\end{array}$ & Often \\
\hline & & $\begin{array}{l}\text { Providing additional activities in the } \\
\text { learning process. }\end{array}$ & Always \\
\hline & & $\begin{array}{l}\text { Students can choose the videos they } \\
\text { want on YouTube. }\end{array}$ & $\begin{array}{l}\text { Sometime } \\
\mathrm{s}\end{array}$ \\
\hline \multirow[t]{4}{*}{4} & $\begin{array}{l}\text { Assessment, } \\
\text { Evaluation }\end{array}$ & $\begin{array}{l}\text { Prepare an assessment for each learning } \\
\text { activity. }\end{array}$ & Often \\
\hline & & $\begin{array}{l}\text { Providing a learning video link on } \\
\text { YouTube for students to learn at home. }\end{array}$ & Often \\
\hline & & $\begin{array}{l}\text { Giving an objective assessment } \\
\text { according to the conditions while } \\
\text { learning. }\end{array}$ & Always \\
\hline & & $\begin{array}{l}\text { Evaluating the learning method after } \\
\text { class. }\end{array}$ & Always \\
\hline
\end{tabular}

This steps were based on the items of the questionnaires given to teachers in order to find out the data in implementing YouTube video. From this table, it showed that there were 4 steps in implementing YouTube video such as preparation, opening, main activity, and assessment. The preparations step was the first step which teacher need to do before starting the class. In this steps there were 6 items which explained the detail of the steps. Teachers were prepared everything they need in the teaching process such as wrote clearly the title and the link of the video in the lesson plan that they made and preparing the media to support the teaching process using YouTube video. Moreover, teachers were using YouTube.com as the main source of video which provide many kinds of video related to the topic in teaching English. In choosing the video, teachers need to choose the video with a proper duration to maximize the teaching process. Based on the data result, it revealed that teachers were prepared everything for learning English activity maximally. Teachers always give questions related to the topic of learning to students as the opening of the lesson. The questions were used to check the students' readiness to accept the lesson and the knowledge whether the students familiar with the topic.

Teachers always give questions related to the topic of learning to students as the opening of the lesson. The questions were used to check the students' readiness to accept the lesson and the knowledge whether the students familiar with the topic. In addition, assessment was often conduct after the main learning activity done by teachers. Teachers always conduct assessment for each learning activity objectively according to the conditions while implementing YouTube video in the class. Besides, teachers often provide a video link from YouTube.com with learning material which students can use it to learn at home or as an assignment. The students can learn it easily because the video can be played repeatedly. Additionally, teachers always evaluate the learning method after the class in order to improve Jurnal Pendidikan Bahasa Inggris Indonesia | 4 
the quality of the learning in another meeting.

The data also explained more about the way teachers implemented YouTube videos in teaching English as a foreign language by targeting several specific skills in English such as for teaching speaking, listening, and vocabulary. As mentioned in Watkins \& Wilkins, (2011), teachers can use YouTube videos to explore students' speaking and listening skill since YouTube can only be enjoyed with sight and hear. Furthermore, YouTube videos can be a media to give an example of role play activity because students can imitate the role in the video given by their teacher.

Table 2. The Summary of Students' Opinion in Skill Development

\begin{tabular}{|c|c|c|c|}
\hline No. & $\begin{array}{c}\text { Skill } \\
\text { Development }\end{array}$ & Item & Category \\
\hline 1 & $\begin{array}{l}\text { Vocabulary } \\
\text { development }\end{array}$ & $\begin{array}{l}\text { Be able to remember more } \\
\text { vocabularies }\end{array}$ & Sometimes \\
\hline 2 & $\begin{array}{l}\text { Speaking } \\
\text { development }\end{array}$ & $\begin{array}{l}\text { Be able to say English words better } \\
\text { Be able to speak spontaneously } \\
\text { Be able to speak fluently }\end{array}$ & $\begin{array}{l}\text { Sometimes } \\
\text { Sometimes } \\
\text { Sometimes }\end{array}$ \\
\hline 3 & $\begin{array}{l}\text { Motivation } \\
\text { development }\end{array}$ & $\begin{array}{l}\text { Motivated in learning English } \\
\text { More interesting in English }\end{array}$ & $\begin{array}{l}\text { Often } \\
\text { Often }\end{array}$ \\
\hline 4 & $\begin{array}{l}\text { Literature } \\
\text { development }\end{array}$ & $\begin{array}{l}\text { Be able to write more sentences well } \\
\text { Be able to understand the discussion } \\
\text { topic }\end{array}$ & $\begin{array}{l}\text { Often } \\
\text { Often }\end{array}$ \\
\hline 5 & $\begin{array}{l}\text { Critical thinking } \\
\text { development }\end{array}$ & $\begin{array}{l}\text { Be able to think critically with the } \\
\text { topic }\end{array}$ & Sometimes \\
\hline
\end{tabular}

The data revealed that most of the students gave positive responses to their opinion about the implementation of YouTube. The items were categorized into 6 categories such as Vocabulary development, Speaking development, Writing development, Listening development, Motivation, Literature development. Students explained that sometimes students gained development in speaking by the implementation of YouTube videos in learning English in the class. Moreover, the students explained that sometimes students were able to say English words in a better way after the implementation of the YouTube video.

The other data also found that sometimes students were able to speak more spontaneously and fluently than before learning using YouTube video. The implementation of YouTube videos also developed students writing skills. The data mentioned that students often able to write more sentences after the implementation of YouTube videos in the class. This data also mentions that sometimes students were able to write sentences better according to the sentence pattern correctly. The data also found out that this technique developed students' literature acquisition which made students understand better and easier. Moreover, the students explained that sometimes this technique gave them a chance to think more critically. Specifically, the students revealed that this technique can be the alternative way of learning English while the school is close due to the Covid-19 pandemic spreading especially in Bali Province.

Most of the respondents stated that they have better understanding while the YouTube video implemented in their class. Furthermore, some of the students answered that they have clearer and easier way in learning English because they can repeat or replay the video in YouTube.com to get better understanding. Moreover, the implementation of YouTube video gave students some development in other category in English acquisition. The data mentioned that the implementation of YouTube video gained students' speaking skill development. This data was in line with Watkins \& Wilkins, (2011) statement which mentioned about the implementation of YouTube video improved students speaking skill since students can explore their speaking skill by using sight and hear sense. The other development category was vocabulary development. This statement was in line with the findings in the previous researches from Styati, (2016), and Kabooha \& Elyas, (2015), the researches revealed that the implementation of YouTube video developed students vocabulary comprehension and recognition. These previous studies also mentioned that the use of YouTube video in learning English facilitated students to gain new vocabulary items 
from the video. Moreover, the implementation of YouTube video increased students' motivation in learning English. The previous statement was supported by the previous studies which conducted by Rahayu \& Putri (2019), and Kabooha \& Elyas (2015).

The respondents stated that the implementation of YouTube video in the class was made the learning process became more efficient because teacher implemented this method in interesting and fun way which decreased the flatness in learning English. In addition, a respondent explained that by implementing YouTube video in learning English in the class, it can be a media in learning English and increase the students' critical thinking. The statement was supported by the findings of the previous research which conducted by Rahayu \& Putri (2019) which mention that the implementation of YouTube video in learning English increased students' creativity, critical thinking, and motivation.

Table 3. The Category of Problem Faced by Teacher in Implementing YouTube Video

\begin{tabular}{|c|c|c|c|}
\hline No. & Problem & Item & Category \\
\hline \multirow[t]{6}{*}{1} & Pre-class & Internet connection problem & Sometimes \\
\hline & & Video Preparation & Sometimes \\
\hline & & Video appropriateness & Never \\
\hline & & Unsuitable topics & Never \\
\hline & & Video availability & Never \\
\hline & & Copyright problem & Never \\
\hline \multirow[t]{6}{*}{2} & In-class & Facilities problem & Never \\
\hline & & Video difficulties & Sometimes \\
\hline & & Language used problem & Sometimes \\
\hline & & Advertisement problem & Sometimes \\
\hline & & Students' understanding & Sometimes \\
\hline & & Students' interest & Never \\
\hline \multirow[t]{3}{*}{3} & Assessment & The learning outcomes & Never \\
\hline & & The effectiveness & Never \\
\hline & & $\begin{array}{l}\text { The difficulties in developing the } \\
\text { technique }\end{array}$ & Never \\
\hline
\end{tabular}

This data revealed that teachers did not have experienced severe problems in preparing the content and the topic in the YouTube video. The data mentioned that sometimes the internet connection was inadequate while preparing and choosing the proper video from YouTube.com which related with the topic of learning to use in teaching English. The teachers were never find problem in choosing the appropriate content for teaching English using YouTube video. The students were never find problem in choosing video which suitable with the topic of learning in YouTube.com. in line with the previous statement, the data revealed that teachers were never experienced problem in choosing proper video because of the diverse of the video availability in YouTube. Moreover, teachers never find out the video with copyright which sometimes cannot be opened. However, this data also found out that sometimes teachers took longer time to prepare the material in teaching English using YouTube. This problem might happen mostly because of the lack of internet connection.

Sometimes students experienced obstacle in understanding the language used in the video which was the English language. Moreover, sometimes problems occurred while implementing YouTube video by teachers such as many advertisements popped up when starting the video and in the middle of the video. The other problem happened was sometimes the students' ability in English was not match with the difficulty level of the video. The data also mentioned that sometimes students experienced problem in understanding on how to implement YouTube video technique. Additionally, the data revealed that he implementation of YouTube video in learning English was interesting to students since the students choose "never" to respond the questionnaire item.

The last problem categorization explained the assessment problem faced by the teachers after implementing YouTube video to teach English in the class. The items in this table showed that students gave positive responds to the three items by choosing "never" as the respond. The first item in this table was explained that students increased their learning 
English outcomes after the implementation of YouTube video. Another item responded that the implementation of YouTube video technique was effective in the process of learning English. Moreover, the last item was revealed that there were no difficulties in developing the learning techniques using YouTube video

Most of the problems were faced by the teachers while implementing the YouTube video in the class and preparing the video which has the same level as the students. The main problem that teachers faced was inaccessible internet connection which is the most crucial thing in implementing the YouTube video technique, because teachers need to play the video directly from the link or the website www.YouTube.com for learning. Moreover, other problems found by the teachers were the students' readiness to accept the lessons and the difficulty level of the topic in the video compared with the students' level. Besides, the data obtained from the questionnaire explained the common problem when implementing YouTube videos: the internet connection and the students' readiness to accept the English lesson.

Table 4. The Category of Problem Faced by Students while the Implementation of YouTube Video

\begin{tabular}{|c|c|c|c|}
\hline No. & Problem & Item & Category \\
\hline \multirow[t]{3}{*}{1} & Technical & Learning facilities problem & Sometimes \\
\hline & & Internet connection problem & Sometimes \\
\hline & & Feature problem & Sometimes \\
\hline \multirow[t]{5}{*}{2} & Content & The content difficulties & Sometimes \\
\hline & & Advertisement problem & Often \\
\hline & & Dialect problem & Sometimes \\
\hline & & Copyright problem & Sometimes \\
\hline & & The video does not match & Sometimes \\
\hline \multirow[t]{2}{*}{3} & Topic & Cultural differences & Sometimes \\
\hline & & Topic suitability & Sometimes \\
\hline 4 & Preferences & Students' interest & Sometimes \\
\hline
\end{tabular}

The category of problems faced by students consisted of Technical, Content, Topic, and Preferences. The first category explained the technical problem which consisted of the internet connection, signals, facilities to support the learning process, and the advertisement popped up at the beginning of the video. The second explained the content of the video which was too fast. The third showed that the topic of the video which difficult to understand because the video was too fast. The last problem explained the preferences of students while the implementation of YouTube video. This last category consisted of the lack of concentration of students which decreased their focus in the learning process.

The result explained that the most mentioned problem was the inadequate internet connection which already mentioned in the previous table. Students needed a better internet connection to access YouTube videos because accessing video on the internet is harder than a picture or text file. In addition, it can be concluded that internet connection is crucial in the implementation of YouTube videos in the learning activity. Some respondents mentioned that the problem when accessing the video on YouTube.com was the advertisement that played at the beginning of the video. It took several seconds to wait until the video that students searched to be played. Furthermore, some students revealed that the problem they faced while watching the video was the explanation in the video was too fast which made the students did not catch the point in the video. In this case, it could be happened because of the lack of students' language acquisition. This data supported the previous table with additional information.

Table 5. The Categorization of Students' Perception toward the Implementation of YouTube Video

\begin{tabular}{cccc}
\hline No. & $\begin{array}{c}\text { Perception } \\
\text { Category }\end{array}$ & \multicolumn{1}{c}{ Indicator } & Category \\
\hline $\mathbf{1}$ & General & $\begin{array}{l}\text { Students enjoyed learning English using } \\
\text { YouTube video }\end{array}$ & Sometimes \\
& &
\end{tabular}




\section{$2 \quad$ Specific}

Easy to understand

The audio quality was good

The visual quality was good

Videos with learning topics are

appropriate

The language used can be understood

well

The difficulty level of the topic was

appropriate

YouTube provided many videos that fit

the learning topic

Pronunciation increased

Vocabulary increased

Fluency increased

Speaking skill improvement

Motivation improvement

Content understanding

The effectiveness of using YouTube
Sometimes

Sometimes

Often

Often

Sometimes

Sometimes

Often

Sometimes

Sometimes

Sometimes

Sometimes

Often

Often

Often

The 35 respondents showed positive perceptions of the implementation of YouTube videos in learning English based on their experience. Generally, students believed that learning English using YouTube videos is good and effective to improve their English acquisition. Furthermore, the respondents explained that the implementation of YouTube videos in learning English was interesting because it gave a better and easy understanding. YouTube video gave students a chance to play the video repeatedly as many as students need. It means that students can watch the video repeatedly until they understand the material in the video. In addition, YouTube videos provided diverse learning content which gave students many chances to choose the video properly and appropriate with their level.

Specifically, the data mentioned that students became even more active and interactive in learning English by using YouTube videos. Moreover, the respondents mention that there were some benefits of implementing YouTube videos in learning English. The first was YouTube video gave students improvement in vocabulary acquisition which beneficial in English language skills. Moreover, YouTube videos combined the sound and visual to watch by the users. Furthermore, YouTube videos may stimulate users in order to improve their listening skills. Thus, users may have better and clear pronunciations from the video. Some respondents were mentioned that learning English using YouTube improved their speaking skills especially in fluency and accuracy in saying words. This could be happened because of the clear sound of the video and the listening skill of the students.

In addition, some respondents explained that learning English using YouTube video gave them benefits to learn more about the English language, especially the students are a vocational tourism student which need to acquire the English language in order to give a better service to their guests. Thus, YouTube video provided many videos with a native speaker of English which can help the students to learn the accent and pronunciation in order to easily adapted with the foreigner. From this data, it can conclude that the students were enjoyed learning English using YouTube videos.

The study finds that the implementation of YouTube video in teaching and learning English was gave positive impact to students' English acquisition and helpful for teacher in delivering the topic to students. This statement was supported by the data in the findings. Moreover, this result was in line with the result in the previous studies. The previous studies were found that the implementation of YouTube video was effective in learning English.

This study showed that teachers were ready to implement YouTube video as media in teaching English as a foreign language to students. Teachers were implemented this media in several different ways and to target different skill in English. Teacher used proper tools to support the teaching activity as well. In addition, the school was supported teachers by providing the proper tools needed by teachers and students in the class. Furthermore, the result of the present study was explained that students have better achievement in English 
acquisition after YouTube video implemented in learning activity. Most of the students mentioned that the implementation of YouTube video in learning English was enhanced their vocabulary and speaking acquisition. However, the data revealed that sometimes problem may occur when implementing YouTube video in learning activity which most common problem happened was the inadequate internet connection since it is the important thing for accessing YouTube.com. Nevertheless, students have positive perceptions about the implementation of YouTube in learning English. Students mentioned that YouTube video gave motivation to learn more about English language and is an interesting way to learn English. In addition, YouTube video gave an improvement to students speaking skill because they can imitate the dialect of native speaker trough watching the video. From the result of this study, there were three implications related to this study.

\section{CONCLUSION AND SUGGESTIONS}

The study revealed that the teachers and students responded positively to the implementation of YouTube video in learning English in the class, however, there were some problems still happen while the implementation of YouTube video. The 5 tenth grade English teachers of SMK Werdhi Sila Kumara understood the way to implement YouTube video in teaching English to students and ready with the tools needed while delivering the learning materials. This statement was supported by the variety of English skills which the teachers targeted in implementing YouTube videos. Moreover, teachers conducted YouTube video in different methods depending on the target skill.

Furthermore, the students acquired several improvements for their achievement in English. The data showed that most of the respondents obtained that the implementation of YouTube videos in learning English gave them better comprehension and understanding of the topic given by their teacher. Moreover, students gained their vocabularies and pronunciation improvement after the implementation of the YouTube video. In addition, the data mentioned that implementing YouTube videos in learning English in the classroom made the time more effective because it gave more time to practice. The students believed that YouTube video gained their interest in learning English because it gave a fun way of learning which decreased the flatness. Besides, the data of the respondents revealed that the implementation of YouTube video could be the alternative way of learning while the school closures due to the Covid-19 pandemic spreading especially in Bali Province.

There were some problems occurred while implementing YouTube video in classroom which obtained by the teachers and students. The problem faced by teachers and students were have some similarities. The lack of the internet connection and the other facilities to support the learning activity were not ready sometimes. Besides, those facilities were vital in the implementation of YouTube video in the class. However, this data revealed that teachers and students did not have experienced severe problems in preparing and understanding the content and the topic in the YouTube video because teachers never gave unsuitable and inappropriate contents or topics to students due to the diverse of video availability in the YouTube.com.

In addition, students of SMK Werdhi Sila Kumara have obtained some positive perception toward the implementation of YouTube videos in learning English. The majority of respondents enjoyed learning English using YouTube videos. However, teachers need to combine and improve the teaching methods with other methods in order to give students varieties and to avoid the flatness in learning English. The students revealed that they have a better understanding of learning YouTube because learning English using YouTube video was easy to understand. Based on the data above, students revealed that learning English using YouTube video made students motivated to learn English more. In addition, the respondents answered that the YouTube video was effective for learning English in the class.

Based on the research findings, the discussion and the conclusion, there are several suggestions that can be suggested, such as the observed 5 tenth grade English teachers of SMK Werdhi Sila Kumara need to develop themselves in teaching English and implementing the YouTube video in interesting way. Besides, the teachers have to solve the problem perceived by students in order to give better understanding in learning English. The school needs to provide some facilities developments in order to develop the teachers and student's readiness in teaching and learning English by using YouTube video since the data revealed 
that the implementation of YouTube video improved students' English acquisition. Further research is recommended to be done in the future especially concerning the implementations of YouTube video in the school with different levels of students and implemented with different ways.

\section{REFERENCES}

Abdulrahman Almurashi, W. (2016). the Effective Use of Youtube Videos for Teaching English. International Journal of English Language and Linguistics Research, 4(3), 3247. http://www.eajournals.org/wp-content/uploads/The-Effective-Use-of-YoutubeVideos-for-Teaching-English-Language-in-Classrooms-as-Supplementary-Material-atTaibah-University-in-Alula.pdf

Ayu, L. P. (2016). E-ISSN 2528-746X YouTube Videos in Teaching Listening: The benefits in Experts' Views. In Research in English and Education (READ) (Vol. 1, Issue 2). http://www.jim.unsyiah.ac.id/READ/article/viewFile/2584/1376

Gilakjani, A. P., \& Sabouri, N. B. (2016). The Significance of Listening Comprehension in English Language Teaching. Theory and Practice in Language Studies, 6(8), 1670. https://doi.org/10.17507/tpls.0608.22

Kabooha, R., \& Elyas, T. (2015). The impacts of using YouTube videos on learning vocabulary in Saudi EFL classroom. ICERI2015 Conference, December 2016, 35253531.

https://www.researchgate.net/publication/283153582 THE IMPACTS OF USING YO UTUBE VIDEOS ON LEARNING VOCABULARY IN SAUDI EFL CLASSROOMS

Kompas.com (2019). APJII: Jumlah Pengguna Internet di Indonesia Tembus 171 Juta Jiwa. https://tekno.kompas.com/read/2019/05/16/03260037/apjii-jumlah-pengguna-internetdi-indonesia-tembus-171-juta-jiwa

Lestari, D., \& Prasetyo, Z. K. (2019). A Review on ICT Literacy in Science Learning. https://doi.org/10.1088/1742-6596/1233/1/012097

Medoukali, F. (2015). Developing EFL L earners' Listening Comprehension through YouTube Videos. http://dspace.univbiskra.dz:8080/jspui/bitstream/123456789/5806/1/Farid MEDOUKALI.pdf

Muhammad, A.-I., Alqahtani, E. T., Na'eem, O., \& Abdelrahman, B. (2014). Kingdom of Saudi Arabia Ministry of Higher Education Effectiveness of Using YouTube on Enhancing EFL Students' Listening Comprehension Skills Riyadh-Saudi Arabia. 1-62. https://www.awej.org/images/Theseanddissertation/EbtissamAlqahtani/ebtissamalqahta nifullthesis.pdf

Muhammad, K. (2012). The Use of YouTube in Teaching English Literature. International Journal of Linguistics, 4 (4). https://doi.org/10.5296/iil.v4i4.2930

Nurkholida, E. (2016). Enhancing Listening Skill Based on Authentic Materials in Higher $\begin{array}{lll}\text { Education. } \quad \text { Deiksis, 256-266. } & \text { 08(03), }\end{array}$ https://journal.lppmunindra.ac.id/index.php/Deiksis/article/download/809/845

Rahayu, S. P., \& Putri, W. S. (2019). Uploading speaking assignment to YouTube channel as an effort in increasing student's pronunciation skill. EnJourMe (English Journal of Merdeka): Culture, Language, and Teaching of English, 3(2). https://doi.org/10.26905/enjourme.v3i2.2741

Ratheeswari, K. (2018). Information Communication Technology in Education. Journal of $\begin{array}{llll}\text { Applied and Advanced Research, } & \end{array}$ https://doi.org/10.21839/jaar.2018.v3is1.169

Saiful. (2019). EFL Teachers' Cognition in the Use of Youtube Vlog in English Language Teaching / Saiful / Journal of Foreign Language Education and Technology. Journal of Foreign Language Education and Technology. http://jflet.com/jflet/index.php/jflet/article/view/133 
Styati, E. W. (2016). Effect of YouTube Videos and Pictures Effect of YouTube Videos and Pictures on EFL Students' Writing Performance. Dinamika IImu, 16(2), 2016.

Suryani, A. (2010). ICT IN EDUCATION: ITS BENEFITS, DIFFICULTIES, AND ORGANIZATIONAL DEVELOPMENT ISSUES. Jurnal Sosial Humaniora, 3(2). https://doi.org/10.12962/j24433527.v3i2.643

Wasif Nisar, M., \& Ali, S. (2011). Usage and Impact of ICT in Education Sector; A Study of Pakistan. Australian Journal of Basic and Applied Sciences, 5(12), 578-583.

Watkins, J., \& Wilkins, M. (2011a). Using YouTube in the EFL Classroom. Language Education in Asia, 2(1), 113-119. https://doi.org/10.5746/leia/11/v2/i1/a09/watkins wilkins

Yasin, B., Mustafa, F., \& Permatasari, R. (2018). How Much Videos Win over Audios in Listening Instruction for EFL Learners. Turkish Online Journal of Educational Technology - TOJET, $\quad 17(1), \quad 92-100$. http://ezproxy.lib.uconn.edu/login?url=https://search.ebscohost.com/login.aspx?direct=tr $\underline{\mathrm{ue} \& \mathrm{db}=\text { eric } \& \mathrm{AN}=\mathrm{EJ} 1165770 \& \text { site }=\text { ehost-live }}$ 